\title{
The influence of ripening period length and season on the microbiological parameters of a traditional Brazilian cheese
}

\author{
Valéria M. Cardoso ${ }^{1,2}$, Ricardo S. Dias ${ }^{3}$, Barbara M. Soares ${ }^{1}$, Letícia A. Clementino ${ }^{1}$, \\ Cristiano P. Araújo ${ }^{1}$, Carlos A. Rosa ${ }^{1,4^{*}}$ \\ ${ }^{1}$ Departamento de Microbiologia, Instituto de Ciências Biológicas, \\ Universidade Federal de Minas Gerais, Belo Horizonte, MG, Brazil. \\ ${ }^{2}$ Departamento de Farmácia, Universidade Federal dos Vales do Jequitinhonha e Mucuri, Diamantina, \\ MG, Brazil. \\ ${ }^{3}$ Divisão de Vigilância Sanitária do Instituto Octávio Magalhães, Fundação Ezequiel Dias, \\ Belo Horizonte, MG, Brazil.
}

Submitted: February 03, 2012; Approved: September 10, 2012.

\begin{abstract}
The ripening process of Serro Minas cheese, one of the most popular cheeses produced with raw milk in Brazil, was studied over the course of 60 days of ripening during dry and rainy seasons. Brazilian legislation prohibits the production of cheese from raw milk unless it was submitted to a maturation period greater than 60 days. However Minas Serro cheese is sold within a few days of ripening. A total of 100 samples of Serro cheese were obtained from five farms; 50 samples were collected during the dry season (winter in Brazil) and 50 samples were collected during the rainy season (summer in Brazil). From each farm, ten cheeses were collected during each season after two days of ripening. Our results showed high levels of total and fecal coliforms at the beginning of the ripening period (approximately $4 \log \mathrm{MPN} / \mathrm{g}$ with 3 days of ripening) that decreased with 60 days of ripening reaching almost $1.5 \mathrm{Log}$ MPN/g. Contamination by coagulase-positive staphylococci was reduced by the end of the ripening period. Salmonella spp. was not detected. The staphylococcal enterotoxins B and C were detected in $1 \%$ and $4 \%$ of the cheeses, respectively, after 30 days of ripening. These results suggest that the ripening process was not effective in eliminating staphylococcal enterotoxins from the cheese. However, none of the investigated strains of Staphylococcus spp. isolated from Serro cheese produced enterotoxins A, B, C or D. The high pathogen and coliform levels at the beginning of the ripening process for the cheese produced during both seasons indicate the need for improvement of the sanitation of the manufacturing conditions.
\end{abstract}

Key words: traditional Minas cheese, ripening, total and fecal coliforms, coagulase-positive staphylococci, staphylococcal enterotoxins.

\section{Introduction}

Traditional cheeses originate from a complex system which results in unique organoleptic characteristics, and they are characterized by strong links to their territory of origin (Lecitra, 2010). Traditional Minas cheese is one of the most popular cheese produced in Brazil, with a long history of manufacturing. Serro cheese is the original name of a variety of Minas cheese produced using raw cow's milk in a region located in the central northeast of Minas Gerais state. It is a very popular cheese in Brazil, and it is considered a variety of semi-hard cheese because it has a typical and markedly acidic taste (Furtado et al., 2003). Serro cheese has been made at the farm house level using traditional procedures for the last 200 years and has high consumption and appreciation levels in Brazil. The Minas Serro cheese producing-region is composed of ten small 
cities, and the region produces about 3,106 tons of cheese per year.

Minas Serro cheese is traditionally made using raw cow's milk and by adding "pingo" (a natural fermentation starter) and industrial liquid rennet. Forty to $60 \mathrm{~min}$ after the addition of rennet and "pingo", the coagulum is cut and transferred to plastic molds, where the whey is removed by hand pressing. The cheese is covered with coarse salt on one side and remains that way for approximately seven hours. Next, the cheese is turned and salted on the other side. After another period of resting (approximately 12 hours), the cheese is turned again, and after 24 hours, it is removed from the mold and washed. "Pingo" is the whey that drops from the previous cheese covered with salt (Borelli et al., 2006). Bacterial populations associated with "pingo" include Lactobacillus, Lactococcus and Streptococcus species (Borelli et al., 2006, Lacerda et al., 2011). This cheesemaking process takes place on farms in a room adjacent to the cow barn.

After three days of maturation at room temperature, the cheese is transported to a storage facility where it is weighed, washed again, dried in a drying chamber for one day and vacuum-packed in plastic bags. Afterward, it is refrigerated at approximately $10{ }^{\circ} \mathrm{C}$ and marketed under refrigeration.

Brazilian legislation (Brasil, 2000) prohibits the production of cheese manufactured with raw milk except for those types of cheese that have a maturation period grater than 60 days. Because Minas Serro cheese sells within a few days of ripening and because is manufactured using raw milk, pathogens such as Staphylococcus aureus, Escherichia coli and Salmonella spp. can contaminate the cheese. This contamination, specifically, the presence of coagulase-positive staphylococci and staphylococcal enterotoxins in the cheese, may present a potential health risk to consumers (Aarestrup et al., 1995; Leloir et al., 2003).

This study was performed to examine the populations of coagulase-positive Staphylococcus, both total and fecal coliforms, E. coli and Salmonella spp. in traditional Minas Serro cheese. The presence of staphylococcal enterotoxins (SE) A, B, C and D and of toxic shock syndrome toxin 1 (TSST-1) was also measured.

\section{Materials and Methods}

\section{Sample collection}

A total of 100 samples of Serro cheese were obtained from five farms; 50 samples were collected during the dry season (winter in Brazil) and 50 samples were collected during the rainy season (summer in Brazil). From each farm, ten cheeses were collected during each season after two days of ripening; they were then stored without packaging in a refrigerated room (around $10^{\circ} \mathrm{C}$ ) of a storage facility throughout the 60-day ripening period. The cheeses were turned every day. The average temperature and the relative humidity $(\mathrm{RH})$ of the refrigerated room during the ripening periods were $10.45^{\circ} \mathrm{C}$ with $88.2 \% \mathrm{RH}$ during the dry season and $11.51{ }^{\circ} \mathrm{C}$ with $81.32 \% \mathrm{RH}$ during the rainy season. The cheeses were sampled after 3, 15, 30, 45 and 60 days of ripening. Out of the ten cheeses collected from each producer, two cheeses were sampled during each time of ripening. The samples were then transported to the laboratory under refrigeration for microbiological analyses. For the staphylococcal enterotoxins analyses, the samples were stored at $-20^{\circ} \mathrm{C}$. The samples collected during the dry season were from cheeses manufactured in May and June of 2008 , and the samples collected during the rainy season were from cheeses manufactured in January of 2009. The analyses were performed on cheeses ripened for $3,15,30$, 45 and 60 days under refrigeration to verify the proper maturation period for this type of cheese. In addition, analyses were performed on cheeses manufactured during either the dry or rainy season to determine whether the microbiological parameters are influenced by the season in which the cheese is produced.

\section{Microbiological analyses}

Samples of $25 \mathrm{~g}$ each were homogenized with $225 \mathrm{~mL}$ of $0.1 \%$ peptone water in a Stomacher 400 lab blender (Seward, London, UK) for $1 \mathrm{~min}$, and serial decimal dilutions were prepared using the same diluent. Total and fecal coliform bacteria were counted using the most probable number (MPN) technique. Lauryl sulfate tryptose and Brilliant Green broths (Difco, Detroit, USA) were used to determine the total coliform bacterial counts, and ECMUG broth (Difco), incubated in a water bath at $45.5^{\circ} \mathrm{C}$, was used to determine the fecal coliform bacterial counts. For $E$. coli isolation, a loopful of culture from each gassing EC tube was streaked onto a Levine's eosin-methylene blue (L-EMB) agar plate and incubated for $18-24 \mathrm{~h}$ at $35^{\circ} \mathrm{C}$. Suspected E. coli colonies were transferred to PCA slants incubated for $18-24 \mathrm{~h}$ at $35^{\circ} \mathrm{C}$ and were tested for the presence of indole production, Voges-Proskauer-reactive compounds, methyl red-reactive compounds, citrate, Gram stain and gas production from lactose. The MPN of E. coli was based on the proportion of EC tubes in three successive dilutions that contained E. coli (Downes and Ito, 2001).

Salmonella spp. detection was carried out after preenrichment in $1 \%$ buffered peptone water for $24 \mathrm{~h}$ at $37^{\circ} \mathrm{C}$ and after enrichment in selenite cystine broth (Biobrás, MG, Brazil) and Rapapport-Vassiliadis broth (Biobrás) for $24 \mathrm{~h}$ at $35^{\circ} \mathrm{C}$ and $42{ }^{\circ} \mathrm{C}$, respectively. Enriched cultures were streaked onto Salmonella-Shigella agar (Biobrás) and Hecktoen enteric agar (Biobrás). The plates were incubated at $35^{\circ} \mathrm{C}$ for $48 \mathrm{~h}$. Typical-looking colonies were examined using the Triple Sugar Iron (TSI) agar (Oxoid, UK) or Lysine Iron Agar (LIA) (Oxoid) fermentation tests, urease tests (using Urea broth, Oxoid) and serological tests such as the polyvalent flagellar $(\mathrm{H})$ and polyvalent somatic $(\mathrm{O})$ 
tests (using Murex Salmonella Polyvalent Agglutinating Sera) (Downes and Ito, 2001).

Staphylococcus spp. were counted on Baird-Parker agar (Biobrás) with added egg yolk tellurite after incubation at $37{ }^{\circ} \mathrm{C}$ for $48 \mathrm{~h}$. After growth, Staphylococcus colonies were counted and classified as being either typical or atypical for S. aureus. Typical S. aureus colonies displayed the following phenotypes: jet black to dark grey, smooth, and convex with well-defined contours, off-white edges and an opaque zone. Atypical S. aureus colonies displayed different phenotypes: gray to dark gray and mucoid with the entire margin showing without a halo. Ten colonies from each sample, five typical and five atypical, were selected and transferred to tubes containing nutrient agar (stock culture); they were then tested for the presence of thermonuclease (TNase), catalase and coagulase for the biochemical identification of coagulase-positive Staphylococcus (Downes and Ito, 2001). Coagulase-negative colonies were further tested for furazolidone sensitivity to differentiate Staphylococcus spp. from Micrococcus spp. (Koneman et al., 2001).

\section{Detection of the coagulase gene in isolates of Staphylococcus spp.}

Staphylococcus spp. that presented a negative phenotype for the coagulase test were next analyzed for the presence of the coagulase gene using a polymerase chain reaction (PCR). DNA extraction and PCR were performed according to the methodology described by Aarestrup et al. (1995). The coagulase gene-specific primers Coa 1 (5'-ACCACAAGGTACTGAATCAACG-3') and Coa2 (5'-TGCTTTCGATTGTTCGATGC-3') were used to amplify a fragment of approximately $987 \mathrm{bp}$. The amplicons were analyzed in a $1 \%$ agarose gel, stained with GelRed nucleic acid gel stain (Biotium, Uniscience, USA) and photographed.

\section{Molecular identification of $S$. aureus}

The isolates of Staphylococcus spp. that were positive for the phenotypic coagulase test or the presence of the coagulase gene were next analyzed for the presence of the $S$. aureus TNase gene and were consequently identified as $S$. aureus. For the confirmation of this species, the $n u c$ gene of $S$. aureus species-specific oligonucleotides SAnuc1 (5'-TGCTATGATTGTGGTAGCCATC-3') and SAnuc2 (5'-TCTCTAGCAAGTCCCTTTTCCA-3') were used to amplify a fragment of $420 \mathrm{bp}$ (Baron et al., 2004). S. aureus ATCC 29213 was used as a positive control for the reaction. After amplification, the reactions were analyzed by electrophoresis through a $1 \%$ agarose gel, stained with GelRed nucleic acid gel stain and photographed.

\section{Detection of the staphylococci enterotoxins}

Enterotoxin extractions from Serro cheese samples were performed according to the procedures previously de- scribed by Carmo (2001). The presence of enterotoxins in the extracts was analyzed in triplicate using the optimumsensitivity-plating (OSP) method as described by Robbins et al. (1974). The extracts were tested for standard enterotoxins A, B, C, D and TSST-1. The limit of detection of the test is $0.5 \mu \mathrm{g}$ of toxin per gram of food.

\section{Toxin production by Staphylococcus species}

Strains of Staphylococcus spp. exhibiting similar physiological and biochemical profiles and that did or did not present the $S$. aureus coagulase or TNase genes were pooled to test SEA, SEB, SEC, SED and TSST-1 production using the OSP method. Individual pools comprised one to five strains.

\section{Statistical analyses}

The data were submitted to descriptive statistics, a Normality test and Pearson Correlation using the program SAS Institute Inc. (SAS/STAT. version 8.0, SAS Institute Inc. Cary, NC, USA). An analysis of variance (ANOVA) and mean comparison using Students $t$ test and Scott-Knott test was used to verify differences between seasons and ripening times, respectively, using the program SISVAR 2007 (SISVAR. version 5.0, DEX/UFLA, Lavras, MG, Brazil). The level of statistical significance was set at $\mathrm{p}<0.05$.

\section{Results and Discussion}

The number of total and fecal coliforms in cheese was high within a few days of ripening (approximately $4 \log$ MPN/g with 3 days of ripening) but then decreased throughout the ripening period reaching almost $1.5 \mathrm{Log}$ MPN/g with 60 days of ripening (Table 1). This result was likely due to the reduction of moisture and inhibition by the native microbiota present in the cheese. It is well known that ripening acts as a natural selector, during which lactic acid bacteria normally inhibit pathogens (Nunez et al., 1985). Leite et al. (2001) analyzed the contamination of Minas cheese and observed a decrease of approximately two Logs in the number of fecal coliform bacteria present on the thirty day of ripening. In this study, with 30 days of ripening, the cheese manufactured during the dry season had 2.3 Log MPN/g of total coliforms and 1.84 Log MPN/g of fecal coliforms. These values are lower than what is allowed by Brazilian law (3.69 Log MPN/g for total coliforms and 2.69 Log MPN/g for fecal coliforms) (Brasil, 1996). After 30 days of ripening, the cheese manufactured during the rainy season presented a number of total and fecal coliforms lower than what is allowed by law. The limits allowed by Brazilian law vary depending on the moisture content of the cheese. With 30 days of ripening, a significantly higher amount of total coliforms was observed in cheese produced during the rainy season (3.15 Log MPN/g) as compared with the dry season (2.30 Log MPN/g). The number of fecal coliforms was also significantly higher 
Table 1 - Counts (mean \pm standard deviation) of total and fecal coliforms, Escherichia coli, Staphylococcus spp., and coagulase-positive Staphylococcus along cheese ripening times and seasons (dry and rainy) in traditional Serro Minas cheese, produced in Brazil.

\begin{tabular}{|c|c|c|c|c|c|c|}
\hline \multirow[b]{2}{*}{ Seasons } & \multirow[b]{2}{*}{ Days } & \multicolumn{5}{|c|}{ Microbial counts } \\
\hline & & Total coliforms $^{1}$ & Fecal coliforms ${ }^{1}$ & Escherichia coli ${ }^{1}$ & Staphylococcus spp. ${ }^{2}$ & $\begin{array}{l}\text { Coagulase positive } \\
\text { Staphylococcus }\end{array}$ \\
\hline \multirow[t]{5}{*}{ Dry } & 3 & $3.99 \pm 0.69^{\mathrm{Aa}}$ & $3.80 \pm 0.84^{\mathrm{Aa}}$ & $1.99 \pm 0.81^{\mathrm{Ba}}$ & $6.24 \pm 0.97^{\mathrm{Bb}}$ & $5.41 \pm 1.46^{\mathrm{Aa}}$ \\
\hline & 15 & $3.71 \pm 0.54^{\mathrm{Aa}}$ & $2.72 \pm 0.85^{\mathrm{Bb}}$ & $1.51 \pm 0.71^{\mathrm{Aa}}$ & $6.03 \pm 0.73^{\mathrm{Bb}}$ & $4.78 \pm 2.56^{\mathrm{Aa}}$ \\
\hline & 30 & $2.30 \pm 0.76^{\mathrm{Bb}}$ & $1.84 \pm 0.53^{\mathrm{Bc}}$ & $1.41 \pm 0.79^{\mathrm{Aa}}$ & $6.37 \pm 0.61^{\mathrm{Ab}}$ & $4.10 \pm 2.90^{\mathrm{Aa}}$ \\
\hline & 45 & $2.21 \pm 0.54^{\mathrm{Ab}}$ & $1.31 \pm 0.62^{\mathrm{Ac}}$ & $0.98 \pm 0.64^{\mathrm{Ab}}$ & $6.90 \pm 0.84^{\mathrm{Aa}}$ & $5.19 \pm 2.85^{\mathrm{Aa}}$ \\
\hline & 60 & $1.39 \pm 0.43^{\mathrm{Ac}}$ & $1.05 \pm 0.49^{\mathrm{Bc}}$ & $0.79 \pm 0.28^{\mathrm{Ab}}$ & $6.95 \pm 0.62^{\mathrm{Aa}}$ & $1.32 \pm 2.79^{\mathrm{Ab}}$ \\
\hline \multirow[t]{5}{*}{ Rainy } & 3 & $4.47 \pm 1.48^{\mathrm{Aa}}$ & $4.26 \pm 1.46^{\mathrm{Aa}}$ & $3.49 \pm 1.67^{\mathrm{Aa}}$ & $8.14 \pm 1.80^{\mathrm{Aa}}$ & $7.16 \pm 3.11^{\mathrm{Aa}}$ \\
\hline & 15 & $4.06 \pm 0.90^{\mathrm{Aa}}$ & $3.75 \pm 0.84^{\mathrm{Aa}}$ & $0.93 \pm 1.06^{\mathrm{Ab}}$ & $7.16 \pm 0.92^{\mathrm{Ab}}$ & $7.10 \pm 0.96^{\mathrm{Aa}}$ \\
\hline & 30 & $3.15 \pm 0.82^{\mathrm{Ab}}$ & $2.72 \pm 0.86^{\mathrm{Ab}}$ & $2.12 \pm 0.69^{\mathrm{Ab}}$ & $6.74 \pm 0.54^{\mathrm{Ab}}$ & $2.37 \pm 3.06^{\mathrm{Ab}}$ \\
\hline & 45 & $2.07 \pm 0.85^{\mathrm{Ac}}$ & $1.81 \pm 0.94^{\mathrm{Ac}}$ & $1.72 \pm 0.99^{\mathrm{Ac}}$ & $6.74 \pm 0.52^{\mathrm{Ab}}$ & $3.99 \pm 3.48^{\mathrm{Ab}}$ \\
\hline & 60 & $1.95 \pm 0.61^{\mathrm{Ac}}$ & $1.90 \pm 0.63^{\mathrm{Ac}}$ & $1.46 \pm 0.54^{\mathrm{Ac}}$ & $6.75 \pm 0.31^{\mathrm{Ab}}$ & $1.95 \pm 3.15^{\mathrm{Ab}}$ \\
\hline
\end{tabular}

${ }^{1} \log$ MPN/g (MPN, most probable number). Mean \pm SD $(n=10)$ of determinations of five batches.

${ }^{2} \log \mathrm{cfu} / \mathrm{g}$ (cfu, colony forming units). Mean $\pm \mathrm{SD}(\mathrm{n}=10)$ of determinations of five batches.

${ }^{a, b, c}$ Within a column, different superscript lowercase letters denote significant differences $(p<0.05)$ amongst the different periods of storage for each studied season.

${ }^{\mathrm{A}, \mathrm{B}}$ Within a column, different superscript uppercase letters denote significant differences $(\mathrm{p}<0.05)$ amongst the different seasons for each studied period of storage.

with 15,30 and 60 days of ripening for cheese produced during the rainy season $(3.75 \mathrm{Log} \mathrm{MPN} / \mathrm{g}, 2.72 \mathrm{Log} \mathrm{MPN} / \mathrm{g}$ and $1.90 \mathrm{Log}$ MPN/g, respectively) as compared with the dry season (2.72 Log MPN/g, 1.84 Log MPN/g and 1.05 $\log \mathrm{MPN} / \mathrm{g}$, respectively).

During the ripening process, a reduction in the amount of $E$. coli was also detected. The high numbers of coliforms and $E$. coli found at the beginning of ripening are indicative of poor sanitation conditions during milking because they are similar to those found in milk used for the production of other cheeses (Ordónez and Burgos, 1977; Centeno et al., 1994; Fontán et al., 2001; Borelli et al., 2006; Rosa et al., 2008, Lecitra, 2010). The milk and "pingo" used in the manufacture of the cheese can possess a considerable amount of these microorganisms, as related by other authors who have also analyzed the raw materials used in the production of traditional Minas cheeses (Pinto, 2004; Borelli et al., 2006; Martins, 2006; Lima et al., 2008). The difference in the amount of $E$. coli present between the seasons was only statistically significant for the cheese that ripened for three days (Table 1); a greater number of $E$. coli was counted from the cheese manufactured during the rainy season (3.49 Log MPN/g) than the dry season (1.99 Log MPN/g). When studying the milk used for the manufacture of Serro cheese, Martins (2006) observed counts of $E$. coli slightly higher in the milk sampled during the rainy season. Caridi et al. (2003) also observed higher counts of $E$. coli in artisanal cheese manufactured at higher temperatures as those found during the rainy season in Brazil. According to Ferreira (2004), higher temperatures directly increase the population of microbiota found in cheese, whether it is endogenous, a contaminant or added.

Salmonella spp. were not detected in the 100 samples analyzed. This result is similar to those found by Borelli et al. (2006) and Lima et al. (2008), who studied other varieties of traditional Minas cheeses.

High counts of Staphylococcus spp. were observed during the entire ripening period for the cheeses manufactured during both seasons (Table 1), but the highest counts were found in the cheese manufactured during the rainy season after three and 15 days of ripening $(p<0.05)$. Staphylococci contamination of food is generally associated with its handlers (Carvalho and Serafini, 1996; Normanno et al., 2007). In addition, satisfactory microbiological conditions of raw materials, such as milk or "pingo", are essential to obtain lower counts of Staphylococcus in cheese. High counts of Staphylococcus spp. have been found previously in milk (approximately $4.12 \mathrm{Log} \mathrm{cfu} / \mathrm{mL}$ ) and "pingo" (almost 3.60 Log cfu/ $/ \mathrm{mL}$ ) used in the manufacturing of traditional Minas cheeses (Borelli et al., 2006; Martins, 2006).

In the present study, only after 45 days of ripening the cheeses made during both dry and rainy seasons have counts of coagulate-positive Staphylococcus under the limit allowed by Brazilian law (1000 cfu/g) (Table 1). There were no statistically significant differences $(p<0.05)$ between the seasons regarding the counts of coagulatepositive Staphylococcus. One hundred and forty-six isolates that presented a negative phenotype for coagulase and TNase were analyzed by PCR using primers to amplify the gene Coa, and four were positive for the presence of the coagulase gene (data not shown). Cremonesi et al. (2005) 
suggest that the presence of the coagulase gene it is not necessarily associated with its phenotypic expression.

A decrease of almost $2 \mathrm{Log} \mathrm{cfu} / \mathrm{g}$ in the amount of $S$. aureus was observed throughout the first 30 days of ripening for cheese produced during the rainy season $(p<0.05)$ (Table 2). Only after 15 days of ripening during the rainy season and 45 days during the dry season did the cheese contain an amount of $S$. aureus below the limit of $3 \mathrm{Log}$ $\mathrm{cfu} / \mathrm{g}$ allowed by Brazilian law. Sixty-eight isolates of Staphylococcus spp. that presented a positive phenotype for coagulase and TNase were analyzed by PCR using primers to amplify the gene SAnuc in order to confirm their identities as $S$. aureus, and 41 were positive for the presence of this gene. Approximately $60 \%$ of the isolates that displayed positive phenotypes for coagulase and TNase were confirmed as $S$. aureus. Some SAnuc amplicons determined by PCR are shown in Figure 1. The size of the PCR products obtained from isolates that were positive for the SAnuc gene is approximately $500 \mathrm{bp}$. Forty-nine isolates with phenotypes positive for coagulase and negative for TNase were also tested, among which 13 contained the SAnuc gene and were identified as $S$. aureus.

Staphylococcal food poisoning (SFP) has been demonstrated to be caused by the consumption of foods containing enterotoxins produced by staphylococci. Ingestion of food containing from $20 \mathrm{ng}$ to $<1 \mu \mathrm{g}$ of SEs can cause SFP (Bergdoll, 1989). SEC and TSST-1 were detected in three and five samples, respectively, out of 50 samples from the cheeses manufactured during the dry season, in concentrations $>0.5 \mu \mathrm{g} / \mathrm{g}$ of food. Two samples from the same producer with 30 days of ripening and one sample with 60 days of ripening contained SEC. Although the number of coagulase-positive Staphylococcus on the cheese with 60 days was under $3 \mathrm{Log} \mathrm{cfu} / \mathrm{g}$, SEC was found in one cheese sample. This enterotoxin was likely formed at the beginning of the ripening period when the quantity of coagulase-positive Staphylococcus in the cheese was high. This result suggests that the ripening process is not effective in eliminating staphylococcal enterotoxins form the

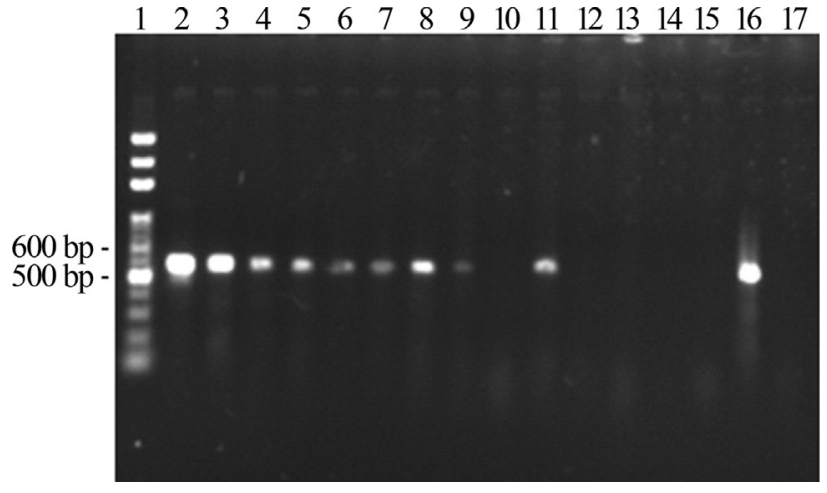

Figure 1 - PCR products of the SAnuc gene from Staphylococcus spp. strains isolated from the Serro Minas cheese that present positive phenotypes for coagulase and Tnase. Lanes: 1: 100 bp DNA ladder; 2: Staphylococcus aureus ATCC 29213; 3, 4, 5, 6, 7, 8, 9, 11 and 16: Staphylococcus spp. isolates that contain the SAnuc gene; 10, 12, 13, 14, 15 and 16: Staphylococcus spp. isolates that did not contain the SAnuc gene.

cheese. Out of the 50 cheese samples obtained during the rainy season, one sample with 30 days of ripening contained SEB, SEC and TSST-1, and 16 samples, with 3 and 15 days of ripening, contained TSST-1 in concentrations $>0.5 \mu \mathrm{g} / \mathrm{g}$ of food. Rosec et al. (1997) and Tamarapu et al. (2001) observed that $66 \%$ of samples from dairy products were positive for SEC, and it has been recognized as an important cause of SFP associated with the consumption of dairy products. Viana et al. (2009) also detected SEB and TSST-1 in samples of "Requeijão do Norte", a traditional semi-hard cheese produced in Brazil.

During the test for the production of enterotoxins and TSST-1 by the isolates of Staphylococcus spp., none of the nine pools analyzed produced the enterotoxins A, B, C and $\mathrm{D}$, although SEB and SEC were detected in one and four cheese samples, respectively. Nevertheless, the isolates of three pools (33.3\% of the analyzed pools) produced TSST1 , which is consistent with the results indicating the presence of TSST-1 in the cheese samples. The TSST-1 detections indicate mastitis in cows that produce milk used to manufacture Serro cheese. Borelli et al. (2006) analyzed

Table 2 - Counts (log mean cfu/g \pm standard deviation) of Staphylococcus aureus, identified based on presence of the gene Sanuc along cheese ripening times and seasons (dry and rainy) in traditional Serro Cheese, produced in Brazil.

\begin{tabular}{lccccc}
\hline \multirow{2}{*}{ Seasons } & \multicolumn{5}{c}{${\text { Counts of } S \text {. } \text { aureus }^{1}}$} \\
\cline { 2 - 6 } & 3 & 15 & Days of ripening & 45 & 60 \\
\cline { 2 - 6 } & $5.13 \pm 2.30^{\mathrm{Aa}}$ & $4.61 \pm 2.48^{\mathrm{Aa}}$ & $3.03 \pm 3.20^{\mathrm{Ab}}$ & $4.75 \pm 3.37^{\mathrm{Aa}}$ & $1.26 \pm 2.66^{\mathrm{Ab}}$ \\
Rry & $5.50 \pm 4.21^{\mathrm{Aa}}$ & $6.93 \pm 0.98^{\mathrm{Aa}}$ & $1.78 \pm 2.87^{\mathrm{Ab}}$ & $1.90 \pm 3.06^{\mathrm{Bb}}$ & $0.70 \pm 2.20^{\mathrm{Ab}}$ \\
\hline
\end{tabular}

${ }^{1} \log \mathrm{cfu} / \mathrm{g}$ (cfu, colony forming units).

Mean \pm SD $(n=10)$ of determinations of five batches.

${ }^{a, b, c}$ Within a line, different superscript lowercase letters denote significant differences $(p<0.05)$ amongst the different periods of storage for each studied season.

${ }^{\mathrm{A}, \mathrm{B}}$ Within a column, different superscript uppercase letters denote significant differences $(\mathrm{p}<0.05)$ amongst the different seasons for each studied period of storage. 
the production of enterotoxins in 19 pools of isolates of Staphylococcus spp. from samples of Canastra Minas cheese and detected the production of SEB, SEC and TSST- 1 in $78.9 \%, 52.6 \%$ and $31.6 \%$ of the pools, respectively. In our study, the detection of TSST-1 was higher in cheeses made during the rainy season after three or 15 days of ripening, when the populations of S. aureus were high.

At the beginning of the cheese ripening process, the initial numbers of coliforms, E. coli and Staphylococcus spp. were very high, possibly because of the lower microbiological conditions of milk; the "pingo" may also have been the cause of high microorganism counts. The cheese produced during the rainy season had higher counts of $E$. coli and Staphylococcus spp. than the cheese produced during the dry season in the beginning of ripening, probably because of a higher number of these microorganisms in milk and pingo produced during that season. Therefore, the contamination of Serro cheeses may be caused by the contamination of raw materials used for their manufacturing, and these materials should be carefully controlled for quality to improve this traditional cheese.

Despite the finding that the investigated strains of Staphylococcus spp. isolated from Serro cheese did not produce enterotoxins, SEB and SEC were found in $4 \%$ of the analyzed cheese samples. Therefore, even though the cheese after at least 45 days of ripening meets the standards established by Brazilian law for coliforms and coagulasepositive Staphylococcus, the presence of SEC in the cheese after 60 days indicates a potential risk for the consumer's health.

\section{Conclusions}

The ripening process has marked effects on the microbiological parameters of traditional Minas Serro cheese. It was effective in reducing the contamination detected by the most important microbiological indicators for contamination of cheese according to Brazilian law, but ripening was not effective in eliminating staphylococcal enterotoxins from the cheese. Once formed, possibly when the counts of coagulase-positive Staphylococcus in the cheese were high, these enterotoxins remained in the cheese even after 60 days of ripening. The high pathogen and coliform levels at the beginning of the ripening process for the cheese produced during both seasons indicates the need for improvement of the sanitation of the manufacturing conditions. Also the high TSST-1 levels at the beginning of the ripening process for the cheese produced during rainy season indicates the need for improvement of the healthiness of herd.

\section{Acknowledgments}

We wish to thank the Cooperativa dos Produtores Rurais do Serro for taking samples and enabling the realization of this study. We also like to thank Fundação Ezequiel
Dias for the contribution on the performance of enterotoxin analyses. Financial support was received from Fundação de Amparo a Pesquisa do Estado de Minas Gerais (FAPEMIG) and Conselho Nacional de Desenvolvimento Científico e Tecnológico (CNPq).

\section{References}

Aarestrup FM, Dangler CA, Sordillo LM (1995) Prevalence of coagulase gene polymorphism in Staphylococcus aureus isolates causing bovine mastitis. Can J Vet Res 59:124-128.

Baron F, Cochet MO, Pellerin JL, Zakour NB, Lebon A, Navarro A, Proudy I, Le Loir Y, Gautier M (2004) Development of a PCR test to differentiate between Staphylococcus aureus and Staphylococcus intermedius. J Food Prot 67:2302-2305.

Bergdoll M S (1989) Staphylococcus aureus. In: Doyle, M. P. (Ed.). Foodborne bacterial pathogens. Marcel Dekker, New York, USA, 463-523.

Borelli BM, Ferreira EG, Lacerda ICA, Santos DA, Carmo LS, Dias RS, Silva MCC, Rosa CA (2006) Enterotoxigenic Staphylococcus spp. and other microbial contaminants during production of Canastra cheese, Brazil. Braz J Microbiol 37:545-550.

Brasil (1996) Regulamentos técnicos de identidade e qualidade dos produtos lácteos. Portaria no. 146, de 7 de março de 1996. Brasília: Diário Oficial da República Federativa do Brasil.

Brasil (2000) Ministério da Agricultura, Pecuária e Abastecimento. Departamento de Inspeção de Produtos de Origem Animal. Resolução no. 07, de 28 de novembro de 2000. Anexo I: Critérios de Funcionamento e de Controle da Produção de Queijarias, para Seu Relacionamento Junto ao Serviço de Inspeção Federal. Brasília: Diário Oficial da República Federativa do Brasil.

Caridi A, Micari P, Caparra P, Cufari A, Sarullo V (2003) Ripening and seasonal changes in microbial groups and in physico-chemical properties of the ewes' cheese Pecorino del Poro. Int Dairy J 13:191-200.

Carmo L S (2001) Produção e Purificação em grande escala das enterotoxinas estafilocócicas SEA, SEB, SEC2, SED e toxina TSST-1 para uso em ensaios imuno-enzimáticos. Belo Horizonte, MG, Brasil, 112 p (Thesis. Departamento de Microbiologia. UFMG).

Carvalho CO, Serafini AB (1996) Grupos de microrganismos isolados de orofaringe, nasofaringe e das mãos de trabalhadores do restaurante da Universidade Federal de Goiás. Hig Alim 10:19-24.

Centeno JA, Rodriguez-Otero JL, Cepeda A (1994) Microbiological study of Arzúa cheese (NW Spain) throughout cheesemaking and ripening. J Food Safety 14:229-241.

Cremonesi P, Luzzana M, Brasca M, Morandi S, Lodi R, Vimercati C, Agnellini D, Caramenti G, Moroni P, Castiglioni B (2005) Development of a multiplex PCR assay for the identification of Staphylococcus aureus enterotoxigenic strains isolated from milk and dairy products. Mol Cel Probes 19:299-305.

Downes FP, Ito K (2001) Compendium of Methods for the Microbiological Examination of Foods. American Public Health Association, Washington, DC.

Ferreira CLLF (2004) Fatores que afetam o crescimento de microrganismos em queijo. Rev Leite Deriv 76:91-96. 
Fontán MCG, Franco I, Prieto B, Tornadijo ME, Carballo J (2001) Microbiological changes in "San Simón" cheese throughout ripening and its relationship with physic-chemical parameters. Food Microbiol 18:25-33.

Furtado MM, Mosquim MCAV, Fernandes AR, da Silva CAB (2003). Produção de queijo minas curado e meia-cura. Projetos de Empreendimentos Agroindustriais: Produtos de Origem Animal. Editora da Universidade Federal de Viçosa, Viçosa, MG.

Koneman EW, Allen SD, Janda WM, Schreckenberger PC, Winn Jr WC (2001) Diagnóstico Microbiológico. Texto e Atlas colorido. Editora Médica e Científica Ltda, Rio de Janeiro, RJ.

Lacerda ICA, Gomes FCO, Borelli BM, Faria Jr. CLL, Franco GR, Mourão MM, Morais P B, Rosa CA (2011) Identification of the bacterial community responsible for traditional fermentation during sour cassava starch, cachaça and Minas cheese production using culture independent 16S rRNA gene sequence analysis. Braz J Microbiol 42:650-657.

Leite RL, Carvalho EP, Moura CJ, Teixeira LAM, Pereira ML (2001) Estudo das condições higiênico-sanitárias de queijos "Minas frescal" e "Minas Padrão" elaborados a partir de leite proveniente de vacas com mastite sub-clínica. Rev Inst Latic "Cândido Tostes" 56:3-11.

Leloir Y, Baron F, Gautier M (2003) Staphylococcus aureus and food poisoning. Genet Mol Res 2:63-79.

Lecitra G (2010) World wide traditional cheeses: Banned for business? Dairy Sci Technol 90:357-374.

Lima CDC, Cerqueira MMOP, Ferreira EG, Faria Jr CLL, Nelson DL, Carmo LS, Rosa CA (2008) Microbiological, physical-chemical and sensory evaluation of a traditional Brazilian cheese during the ripening process. World J Microbiol Biotechnol 24:2389-2395.

Martins JM (2006) Características físico-químicas e microbiológicas durante a maturação do queijo Minas artesanal da região do Serro. Viçosa, MG, Brasil, 87 p. (Thesis, Departamento de Ciência e Tecnologia de Alimentos. UFV).
Normanno G, La Salandra G, Dambrosio A, Quaglia NC, Corrente M, Parisi A, Santagada G, Firinu A, Crisetti E, Celano GV (2007) Occurrence, characterization and antimicrobial resistance of enterotoxigenic Staphylococcus aureus isolated from meat and dairy products. Int J Food Microbiol 115:290-296.

Nunez M, Gaya P, Medina M (1985) Influence of manufacturing and ripening conditions on the survival of Enterobacteriaceae in Manchego cheese. J. Dairy Sci. 68:794-800.

Ordónez, J. A.; Burgos, J. (1977). Étude de La variété de fromage "Ulloa". Le Lait 57:150-153.

Pinto MS (2004) Diagnóstico socioeconômico, cultural e avaliação dos parâmetros físico-químicos e microbiológicos do queijo minas artesanal do Serro. Viçosa, MG, Brasil, 123 p. (M.Sc. Dissertation. Departamento de Ciência e Tecnologia de Alimentos. UFV).

Robbins R, Gould S, Bergdoll MS (1974) Detecting the enterotoxigenicity of Staphylococcus aureus strains. Appl Microbiol 28:946-950.

Rosa TD, Wassermann GE, Souza CFV, Caron D, Carlini CG, Ayub MAZ (2008) Microbiological and physicochemical characteristics and aminopeptidase activities during ripening of Serrano cheese. Int J Dairy Technol 61:70-79.

Rosec JP, Guiraud JP, Dalet C, Richard N (1997) Enterotoxin production by staphylococci isolated from foods in France. Int $\mathrm{J}$ Food Microbiol 35:213-221.

Tamarapu S, Mckillip JL, Drake M (2001) Development of a multiplex polymerase chain reaction assay for detection and differentiation of Staphylococcus aureus in dairy products. J Food Prot 64:664-668.

Viana FR, Oliveira AL, Carmo LS, Rosa CA (2009) Occurrence of coagulase-positive Staphylococci, microbial indicators and physical-chemical characteristics of traditional semihard cheese produced in Brazil. Int J Dairy Technol 62:372-377.

All the content of the journal, except where otherwise noted, is licensed under a Creative Commons License CC BY-NC. 